their plaintive, pure couplets, each on its own individual key of a harmonious minor scale. Yet each two notes, sweet and drawn well out, never interrupted the repeated note of another of the flock. When disturbed they moved on from branch to branch, with little sipping call notes in a worried tone.

Toward evening, other birds sought shelter from the wind. Even a handsome Mallard and his mate waddled across the lawn, pausing to preen their wings; and a Killdeer slanted down and ran along the driveway . . a thing we seldom see in the house yard though they commonly frequent the open ground near the barn.

A flock of swallows materialized out of the sky and took refuge on the powerline wires leading to the house. Here they fluffed up their plumage and tucked in their heads, companionably snuggled together in twos and threes and fours along the wire. They seemed very weary. We could watch them from ring-side seats, by going to the south window upstairs, and found that there were four species among the little band. Most of them were Tree swallows, iridiscent green-on-navy backs with white underparts and blunt V-tails. There were two Barn swallows, with reddish-brown breasts and the long "swallow tail" feathers. One Cliff swallow was clearly identified by his broad white forehead patch, and there were two softly brown Bank swallows with creamy breasts outlined at the throat by a darkish bar. These two also had blunt V-tails. As evening drew on, they cuddled closer together, till they all crowded about a foot of each line, close to the house wall, thankful for the oasis of quiet out of the wind.

Endlessly reiterated, the mourning dove's dismal plaint seemed particularlv suitable to the weather, and to the feelings of all the migrants snowbound here.

Did you know that chickadees like dead honeybees, but they never eat the part with the stinger in it? Our bees died and we cleaned the frames up and put them where we could watch the birds eat, but they dropped the stinger part on the snow.

-Edith Hanson, Viking, Alta.

(Submitted by Marion Nixon)

\section{Wee Things}

This earth is full with tiny things,

Everywhere, always present;

Each little mite in its own right

Is beautiful and pleasant.

In all the world there's never a breeze

But makes some bird wing fleeter;

There's not a leaf among the trees

But makes the scene much sweeter.

There's not one ray of the great, great sun

But makes the day look brighter;

There isn't a song but makes someone

Gayer, gladder, lighter.

And never is there a busy bee

But helps to give the notion

Its work's of prime necessity

To keep this world in motion.

A trickling stream there never was But fed some green grass tender,

And ne'er was there a sparkling drop But helped some sapling slender.

There never was in the wide, wide world

One glorious sunset splendour

But made the heart of some sweet one

Flutter in expectation:

Each gift of every wee, wee thing Helps beautify this great Creation.

John Anton Popoff, Yorkton, April, 1917

From the first week in January for over a month we had a flock of about three dozen Pine Grosbeaks, in a bluff by the house. They seemed to be eating rose berries. There were quite a few males, almost all a bright rosy red. This is the first I've really seen them close up. They are really beautiful.

Mrs. Thomas Lowes, Wimmer, Sask.

Among enemies of the ideals of conservation are the thoughtless, the reckless and the wrongheaded. But I think the one that gives you the cold shudders is the almost completely immoral type, who with no conception of the social consequences of his actions - who dosn't care anyway, and who is governed by his knowledge of what he can get away with. A. J. Hudson, Mortlach 